\title{
MENINGKATKAN PRESTASI BELAJAR PENDIDIKAN AGAMA ISLAM DENGAN MENERAPKAN MODEL PENGAJARAN TUNTAS PADA SISWA KELAS II SD NEGERI 060910 MEDAN DENAI
}

\author{
Nurintan Sianturi \\ Surel: nurintansianturi@yahoo.com
}

\begin{abstract}
ABSTRAK
Penelitian ini bertujuan untuk meningkatkan prestasi belajar Agama Islam siswa kelas II SD Negeri 060910 Medan Denai tahun pelajaran 2014/2015. Penelitian adalah penelitian tindakan (action research) sebanyak tiga putaran. Setiap putaran terdiri dari empat tahap yaitu: rancangan, kegiatan dan pengamatan, refleksi, dan refisi. Sasaran penelitian ini adalah siswa kelas II SD Negeri 060910 Medan Denai tahun pelajaran 2014/2015. Dari hasil analis didapatkan bahwa prestasi belajar siswa mengalami peningkatan dari siklus I sampai siklus III yaitu, siklus I (66,67\%), siklus II (75,56\%), siklus III (86,67\%). Kesimpulan dari penelitian ini adalah model pembelajaran tuntas dapat berpengaruh positif terhadap motivasi belajar Siswa Kelas II SD Negeri 060910 Medan Denai tahun pelajaran 2014/2015, serta model pembelajaran ini dapat digunakan sebagai salah satu alternatif pembelajaran Pendidikan Agama Islam.
\end{abstract}

Kata Kunci: Model Pembelajaran, Pengajaran Tuntas, Prestasi Belajar

\section{PENDAHULUAN}

Menurut teori psikologi, anak yang rasional selalu bertindak sesuai tingkatan perkembangan umur mereka. Ia mengadakan reaksi-reaksi terhadap lingkungannya, atau adanya aksi dari lingkungan maka ia melakukan kegiatan atau aktivitas. Dalam pendidikan kuno aktivitas anak tidak pernah diperhatikan karena menurut pandangan mereka anak dilahirkan tidak lain sebagai "orang dewasa dalam bentuk kecil". Ia harus diajarkan menurut kehendak orang dewasa. Karena itu ia harus menerima dan mendengar apa-apa yang diberikan dan disampaikan orang dewasa/guru tanpa dikritik. Anak tak rubahnya seperti gelas kosong yang pasif menerima apa saja yang dituangkan ke dalamnya.

Di dalam proses belajar mengajar, guru harus memiliki strategi, agar siswa dapat belajar secara efektif dan efisien, mengena pada tujuan yang diharapkan. Salah satu langkah untuk memiliki strategi itu ialah harus menguasai teknikteknik penyajian, atau biasanya disebut metode mengajar. Teknik penyajian pelajaran adalah suatu pengetahuan tentang cara-cara mengajar yang dipergunakan oleh guru atau instrukstur. Pengertian lain

SD Negeri 060910 Medan Denai 
ialah sebagai teknik penyajian yang dikuasai oleh guru untuk mengajar atau menyajikan bahan pelajaran kepada siswa di dalam kelas, agar pelajaran tersebut dapat ditangkap, dipahami dan digunakan oleh siswa dengan baik. Di dalam kenyataan cara atau metode mengajar atau teknik penyajian yang digunakan guru untuk menyampaikan informasi atau massage lisan kepada siswa berbeda dengan cara yang ditempuh untuk memantapkan siswa dalam menguasai pengetahuan, keterampilan serta sikap. Metode yang digunakan untuk memotivasi siswa agar mampu menggunakan pengetahuannya untuk memecahkan suatu masalah yang dihadapi ataupun untuk menjawab suatu pertanyaan akan berbeda dengan metode yang diguanakan untuk tujuan agar siswa mampu berpikir dan mengemukakan pendapatnya sendiri di dalam menghadapi segala persoalan. Kita mengenal bermacam-macam teknik penyajian dari yang tradisional, yang digunakan sejak dahulu kala, tetapi juga yang modern, yang digunakan baru akhir-akhir ini saja.

Perkembangan selanjutnya para ahli masih tersu mengadakan penelitian dan eksperimen agar dapat menemukan teknik penyajian yang dipandang paling efektif untuk pelajaran tertentu. apakah hal itu akan terjawab, kita serahkan pada hasil penelitian para ahli tersebut. Dengan menyadari gejala-gejala atau kenyataan tersebut di atas, maka dalam penelitian ini penulis penulis mengambil judul "Meningkatkan Prestasi Belajar Pendidikan Agama Islam Dengan Menerapkan Model Pengajaran Tuntas Pada Siswa Kelas II SD Negeri 060910 Kec. Medan Denai Pelajaran 2013/2014."

\section{METODE PENELITIAN}

Penelitian ini merupakan penelitian tindakan (Action Research), karena penelitian dilakukan untuk memecahkan masalah pembelajaran di kelas. Penelitian ini juga termasuk penelitian deskriptif, sebab menggambarkan bagaimana suatu teknik pembelajaran diterapkan dan bagaimana hasil yang diinginkan dapat dicapai. Tempat penelitian adalah tempat yang digunakan dalam melakukan penelitian untuk memperoleh data yang diinginkan. Penelitian ini bertempat di SD Negeri 060910 Kec Medan Denai Pelajaran 2013/2014.

Instrumen adalah alat pengumpul data seperti, tes, kuesioner, observasi, skala sikap, sosiometri, wawancara dan lain-lain. Instrumen atau alat ukur dalam penelitian ini adalah berupa tes. Tes adalah alat ukur yang diberikan kepada individu untuk mendapatkan jawaban-jawaban yang diharapkan baik secara tertulis atau lisan atau secara perbuatan (Sudjana dan 
Ibrahim, 1996:100). kemudian penulis mengadakan analisis butir soal tes yang telah diuji validitas dan reliabilitas pada tiap soal. Analisis ini digunakan untuk memilih soal yang baik dan memenuhi syarat digunakan untuk mengambil data.

Sebelum melaksanakan pengambilan data melalui instrumen penelitian berupa tes dan mendapatkan tes yang baik, maka data tes tersebut diuji dan dianalisis. Uji coba dilakukan pada siswa di luar sasaran penelitian. Analisis tes yang dilakukan meliputi:

a. Validitas

Validitas butir soal dimaksudkan untuk mengetahui kelayakan tes sehingga dapat digunakan sebagai instrumen dalam penelitian ini. Dari perhitungan 46 soal diperoleh 10 soal tidak valid dan 30 soal valid. Hasil dari validitas soalsoal dirangkum dalam tabel di bawah ini.

\section{b. Reliabilitas}

Soal-soal yang telah memenuhi syarat validitas diuji reliabilitasnya. Dari hasil perhitungan diperoleh koefisien reliabilitas $r_{11}$ sebesar 0, 423. Harga ini lebih besar dari harga $\mathrm{r}$ product moment. Untuk jumlah siswa $(\mathrm{N}=45$ dengan $\mathrm{r}(95 \%)$ $=0,294$. Dengan demikian soal-soal tes yang digunakan telah memenuhi syarat reliabilitas. Taraf kesukaran digunakan untuk mengetahui tingkat kesukaran soal. Hasil analisis menunjukkan dari 46 soal yang diuji terdapat:

- 22 soal mudah

- 14 soal sedang

- 10 soal sukar

c. Daya Pembeda Analisis

Daya pembeda dilakukan untuk mengetahui kemampuan soal dalam membedakan siswa yang berkemampuan tinggi dengan siswa yang berkemampuan rendah. Dari hasil analisis daya pembeda diperoleh soal yang berkriteria jelek sebanyak 16 soal, berkriteria cukup 21 soal, berkriteria baik 9 soal. Uraian secara lengkap analisis daya pembeda soal tes dapat dilihat pada lampiran. Dengan demikian soal-soal tes yang digunakan telah memenuhi syarasyarat validitas, reliabilitas, taraf kesukaran, dan daya pembeda.

Untuk mengetahui keefektifan suatu metode dalam kegiatan pembelajaran perlu diadakan analisa data. Pada penelitian ini menggunakan teknik analisis deskriptif kualitatif, yaitu suatu metode penelitian yang bersifat menggambarkan kenyataan atau fakta sesuai dengan data yang diperoleh dengan tujuan untuk mengetahui prestasi belajar yang dicapai siswa juga untuk memperoleh respon siswa terhadap kegiatan pembelajaran serta aktivitas siswa selama proses pembelajaran. 
Untuk menganalisis tingkat keberhasilan atau persentase keberhasilan siswa setelah proses belajar mengajar setiap putarannya dilakukan dengan cara memberikan evaluasi berupa soal tes tertulis pada setiap akhir putaran. Analisis ini dihitung dengan menggunakan statistik sederhana yaitu:

1. Untuk menilai ulangan atau tes formatif

Peneliti melakukan penjumlahan nilai yang diperoleh siswa, yang selanjutnya dibagi dengan jumlah siswa yang ada di kelas tersebut sehingga diperoleh rata-rata tes.

2. Untuk ketuntasan belajar

Ada dua kategori ketuntasan belajar yaitu secara perorangan dan secara klasikal. Berdasarkan petunjuk pelaksanaan belajar mengajar kurikulum 1994 (Depdikbud, 1994), yaitu seorang siswa telah tuntas belajar bila telah mencapai skor $65 \%$ atau nilai 65 , dan kelas disebut tuntas belajar bila di kelas tersebut terdapat $85 \%$ yang telah mencapai daya serap lebih dari atau sama dengan $65 \%$.

3. Untuk lembar observasi

a. Lembar observasi pengelolaan model pembelajaran tuntas.

b. Lembar observasi aktivitas guru dan siswa

\section{HASIL DAN PEMBAHASAN}

Data observasi berupa pengamatan pengelolaan model pembelajaran tuntas dan pengamatan aktivitas siswa dan guru pada akhir pembelajaran, dan data tes formatif siswa pada setiap siklus. Data lembar observasi diambil dari dua pengamatan yaitu data pengamatan pengelolaan model pembelajaran tuntas yang digunakan untuk mengetahui pengaruh penerapan model pembelajaran tuntas dalam meningkatkan prestasi belajar siswa dan data pengamatan aktivitas siswa dan guru. Data tes formatif untuk mengetahui peningkatan prestasi belajar siswa setelah diterapkan proses belajar mengajar dengan menerapkan model pembelajaran tuntas.

Pada tahap perencanaan siklus I peneliti mempersiapkan perangkat pembelajaran yang terdiri dari rencana pelajaran 1 , soal tes formatif 1 dan alat-alat pengajaran yang mendukung. Selain itu juga dipersiapkan lembar observasi pengolahan model pembelajaran tuntas, dan lembar observasi aktivitas guru dan siswa.

Pelaksanaan kegiatan belajar mengajar untuk siklus I dilaksanakan pada tanggal 2 April 2014 di Kelas II dengan jumlah siswa 27 siswa. Dalam hal ini peneliti bertindak sebagai pengajar, sedangkan yang bertindak sebagai pengamat adalah kepala 
sekolah dengan dibantu seorang guru. Adapun proses belajar mengajar mengacu pada rencana pelajaran yang telah dipersiapkan. Pengamatan (observasi) dilaksanakan bersamaan dengan pelaksaaan belajar mengajar.

Pada akhir prose belajar mengajar siswa diberi tes formatif I dengan tujuan untuk mengetahui tingkat keberhasilan siswa dalam proses belajar mengajar yang telah dilakukan. Berdasarkan tabel di atas aspek-aspek yang mendapatkan kriteria kurang baik adalah memotivasi siswa, menyampaikan tujuan pembelajaran, pengelolaan waktu dan siswa antusias. Keempat aspek yang mendapat penilaian kurang baik di atas, merupakan suatu kelemahan yang terjadi pada siklus I. Dan akan dijadikan bahan kajian untuk refleksi dan revisi yang akan dilakukan pada siklus II. Aktivitas guru yang paling dominan pada siklus I adalah membimbing dan mengamati siswa dalam menemukan konsep yaitu 20,31\%. Aktivitas lain yang persentasenya cukup besar adalah memberi umpan balik/evaluasi/tanya jawab dan menjelaskan materi yang sulit yaitu masing-masing sebesar $17,19 \%$ dan $12,50 \%$. Sedangkan aktivitas siswa yang paling dominan adalah mengerjakan/ memperhatikan penjelasan guru yaitu $21,09 \%$. Aktivitas lain yang persentasenya cukup besar adalah bekerja dengan sesama siswa, diskusi antar siswa/antara siswa dengan guru, dan membaca buku yaitu masing-masing $17,58 \% 13,48$ dan $10,74 \%$.

Pada siklus I, secara garis besar kegiatan belajar mengajar dengan model pembelajaran tuntas sudah dilaksanakan dengan baik, walaupun peran guru masih cukup dominan untuk memberikan penjelasan dan arahan karena model tersebut masih dirasakan baru oleh siswa. Dapat dijelaskan bahwa dengan menerapkan model pembelajaran tuntas diperoleh nilai rata-rata prestasi belajar siswa adalah 68,22 dan ketuntasan belajar mencapai $66,67 \%$ atau ada 20 siswa dari 27 siswa sudah tuntas belajar. Hasil tersebut menunjukkan bahwa pada siklus pertama secara klasikal siswa belum tuntas belajar, karena siswa yang memperoleh nilai $\geq 65$ hanya sebesar $66,67 \%$ lebih kecil dari persentase ketuntasan yang dikehendaki yaitu sebesar $85 \%$. Hal ini disebabkan karena siswa masih merasa baru dan belum mengerti apa yang dimaksudkan dan digunakan guru dengan menerapkan model pembelajaran tuntas.

Dalam pelaksanaan kegiatan belajar mengajar diperoleh informasi dari hasil pengamatan sebagai berikut:

1) Guru kurang maksimal dalam memotivasi siswa dan dalam menyampaikan tujuan pembelajaran 
2) Guru kurang maksimal dalam pengelolaan waktu

3) Siswa kurang aktif selama pembelajaran berlangsung

Kegiatan belajar mengajar pada siklus I ini masih terdapat kekurangan, sehingga perlu adanya revisi untuk dilakukan pada siklus berikutnya. Pada tahap perencanaan siklus II peneliti mempersiapkan perangkat pembelajaran yang terdiri dari rencana pelajaran 2, soal tes formatif 2 dan alat-alat pengajaran yang mendukung. Selain itu juga dipersiapkan lembar observasi pengelolaan model pembelajaran tuntas dan lembar observasi guru dan siswa.

Pelaksanaan kegiatan belajar mengajar untuk siklus II dilaksanakan pada tanggal 9 April 2014 di kelas II dengan jumlah siswa 27 siswa. Kepala sekolah dengan dibantu seorang guru. Adapun proses belajar mengajar mengacu pada rencana pelajaran dengan memperhatikan revisi pada siklus I, sehingga kesalahan atau kekurangan pada siklus I tidak terulang lagi pada siklus II. Pengamatan (observasi) dilaksanakan bersamaan dengan pelaksanaan belajar mengajar. Pada akhir proses belajar mengajar siswa diberi tes formatif II dengan tujuan untuk mengetahui tingkat keberhasilan siswa dalam proses belajar mengajar yang telah dilakukan. Instrumen yang digunakan adalah tes formatif II kegiatan belajar mengajar (siklus II) yang dilaksanakan oleh guru dengan menerapkan model pembelajaran tuntas mendapatkan penilaian yang cukup baik dari pengamat. Maksudnya dari seluruh penilaian tidak terdapat nilai kurang. Namum demikian penilaian tersebut belum merupakan hasil yang optimal, untuk itu ada beberapa aspek yang perlu mendapatkan perhatian untuk penyempurnaan penerapan pembelajaran selanjutnya. Aspekaspek tersebut adalah memotivasi siswa, membimbing siswa merumuskan kesimpulan/ menemukan konsep, dan pengelolaan waktu. Dengan penyempurnaan aspek-aspek di atas dalam penerapan model pembelajaran tuntas diharapkan siswa dapat menyimpulkan apa yang telah mereka pelajari dan mengemukakan pendapatnya sehingga mereka akan lebih memahami tentang apa yang telah mereka lakukan. Aktivitas guru yang paling dominan pada siklus II adalah membimbing dan mengamati siswa dalam menemukan konsep yaitu 23,44\%. Jika dibandingkan dengan siklus I, aktivitas ini mengalami peningkatan. Selain itu aktivitas guru yang mengalami peningkatan adalah menjelaskan materi yang sulit sebesar 14,06\%. Meminta siwa mendiskusikan dan menyajikan hasil kegiatan $10,93 \%$. 
Disamping itu ada juga aktivitas guru yang mengalami penurunan antara lain memotivasi siswa dan mengaitkan dengan materi sebelumnya masing-masing menjadi $6,25 \%$, memberi umpan balik menjadi $15,63 \%$ dan membimbing siswa merangkum pelajaran menjadi $6,25 \%$.

Sedangkan untuk aktivitas siswa yang paling dominan pada siklus II adalah bekerja dengan sesama siswa yaitu 19,53\%. Jika dibandingkan dengan siklus I, aktivitas ini mengalami peningkatan. Aktivitas siswa yang mengalami peningkatan adalah membaca buku menjadi 13,67\%, diskusi antar siswa/antar siswa dengan guru menjadi $14,06 \%$, menyajikan hasil pembelajaran menjadi $7,42 \%$, mengajukan pertanyaan/ide dan merangkum pemelajaran masingmasing menjadi $9,38 \%$.

Aktivitas lainnya yang mengalami penurunan adalah menulis yang relevan dengan KBM menjadi $12,11 \%$ dan mengerjakan tes evaluasi menjadi $6.25 \%$, nilai rata-rata prestasi belajar siswa adalah 74,67 dan ketuntasan belajar mencapai $75,56 \%$ atau ada 34 siswa dari 45 siswa sudah tuntas belajar. Hasil ini menunjukkan bahwa pada siklus II ini ketuntasan belajar secara klasikal telah mengalami peningkatan sedikit lebih baik dari siklus I Adanya peningkatan hasil belajar siswa ini karena setelah guru menginformasikan bahwa setiap akhir pelajaran akan selalu diadakan tes sehingga pada pertemuan berikutnya siswa lebih termotivasi untuk belajar. Selain itu siswa juga sudah mulai mengerti apa yang dimaksudkan dan dinginkan guru dengan menerapkan model pembelajaran tuntas.

Dalam pelaksanaan kegiatan belajar diperoleh informasi dari hasil pengamatan sebagai berikut:

1. Memotivasi siswa

2. Membimbing siswa merumuskan kesimpulan/menemukan konsep

3. Pengelolaan waktu

$$
\text { Revisi Rancangan }
$$

Pelaksanaan kegiatan belajar pada siklus II ini masih terdapat kekurangan-kekurangan. Maka perlu adanya revisi untuk dilaksanakan pada siklus II antara lain:

1. Guru dalam memotivasi siswa hendaknya dapat membuat siswa lebih termotivasi selama proses belajar mengajar berlangsung.

2. Guru harus lebih dekat dengan siswa sehingga tidak ada perasaan takut dalam diri siswa baik untuk mengemukakan pendapat atau bertanya.

3. Guru harus lebih sabar dalam membimbing siswa merumuskan kesimpulan/ menemukan konsep.

4. Guru harus mendistribusikan waktu secara baik sehingga 
kegiatan pembelajaran dapat berjalan sesuai dengan yang diharapkan.

5. Guru sebaiknya menambah lebih banyak contoh soal dan memberi soal-soal latihan pada siswa untuk dikerjakan pada setiap kegiatan belajar mengajar.

6. Guru seharusnya menggunakan metode metode baru dalam memotivasi semangat siswa, karena metode yang membosankan/monoton membuat siswa malas untuk melanjutkan pembelajaran.

Pada tahap perencanaa siklus III peneliti mempersiapkan perangkat pembelajaran yang terdiri dari rencana pelajaran 3 , soal tes formatif 3 dan alat-alat pengajaran yang mendukung. Selain itu juga dipersiapkan lembar observasi pengelolaan model pembelajaran tuntas dan lembar observasi aktivitas guru dan siswa. Tahap kegiatan dan pengamatan Pelaksanaan kegiatan belajar mengajar untuk siklus III dilaksanakan pada tanggal 16 April 2014 di kelas II dengan jumlah siswa 27 siswa. Dalam hal ini peneliti bertindak sebagai pengajar, sedangkan yang bertindak sebagai pengamat adalah kepala sekolah dengan dibantu seorang guru. Adapun proses belajar mengajar mengacu pada rencana pelajaran dengan memperhatikan revisi pada siklus II sehingga kesalahan atau kekurangan pada siklus II tidak terulang lagi pada siklus III. Pengamatan (observasi) dilaksanakan bersamaan dengan pelaksanaan belajar mengajar. Pada akhir proses belajar mengajar siswa diberi tes formatif III dengan tujuan untuk mengetahui tingkat keberhasilan siswa dalam proses belajar mengajar yang telah dilakukan. Instrumen yang digunakan adalah tes formatif III. Dilihat aspekaspek yang diamati pada kegiatanbelajar mengajar (siklus III) yang dilaksanakan oleh guru dengan menerapkan model pembelajaran tuntas mendapatkan penilaian cukup baik dari pengamat adalah memotivasi siswa, membimbing siswa merumuskan kesimpulan/ menemukan konsep, dan pengelolaan waktu.

Penyempurnaan aspek-aspek di atas dalam menerapkan model pembelajaran tuntas diharapkan dapat berhasil semaksimal mungkin. Aktivitas guru yang paling dominan pada siklus III adalah membimbing dan mengamati siswa dalam menemukan konsep yaitu 20,31\%, aspek ini menurun kembali seperti pada siklus I. Sedangkan aktivitas menjelaskan materi yang sulit, meminta siswa menyajikan dan mendiskusikan hasil pembelajaran, memberi umpan balik/evaluasi/tanya jawab menurun masing-masing 
menjadi sebesar $10,94 \%, 6,25 \%$, dan $7,81 \%$ Aktivitas lain yang mengalami peningkatan adalah mengaitkan dengan pelajaran sebelumnya dan menyampaikan langkah-langkah strategis

masing menjadi 10,94 dan $17,19 \%$. Adapun aktivitas yang lain tidak mengalami perubahan. Sedangkan untuk aktivitas siswa yang paling dominan pada siklus III adalah membaca buku yaitu sebesar 19,53\% dan diskusi antar siswa/antar siswa dengan guru menjadi sebesar $19,14 \%$, aspek ini mengalami peningkatan dibanding siklus sebelumnya. aktivitas lain yang mengalami peningkatan adalah mendengarkan/ memperhatikan penjelasan guru menjadi $12,50 \%$, dan mengerjakan tes evaluasi menjadi sebesar $6,844 \%$.

Sedangkan aktivitas

yang mengalami penurunan adalah bekerja sama dengan sesama siswa menjadi 13,87\%, mengajukan pertanyaan/ide menjadi $\quad 5,86 \%$, menulis yang relevan dengan KBM menjadi $7,03 \%$ dan merangkum pembelajaran menjadi $7,81 \%$. Nilai rata-rata tes formatif sebesar 78,60 dan dari 45 siswa yang telah tuntas sebanyak 39 siswa dan 6 siswa belum mencapai ketuntasan belajar. Maka secara klasikal ketuntasan belajar yang telah tercapai sebesar 86,67\% (termasuk kategori tuntas). Hasil pada siklus III ini mengalami peningkatan lebih baik dari siklus II. Adanya peningkatan hasil belajar pada siklus III ini dipengaruhi oleh adanya peningkatan kemampuan guru dalam menerapkan model pembelajaran tuntas sehingga siswa menjadi lebih terbiasa dengan pembelajaran seperti ini sehingga siswa lebih mudah dalam memahami materi yang telah diberikan.

Pada tahap ini akan dikaji apa yang telah terlaksana dengan baik maupun yang masih kurang baik dalam proses belajar mengajar dengan menerapan model pembelajaran tuntas. Dari data-data yang telah diperoleh dapat duraikan sebagai berikut:

1. Selama proses belajar mengajar guru telah melaksanakan semua pembelajaran dengan baik. Meskipun ada beberapa aspek yang belum sempurna, tetapi persentase pelaksanaannya untuk masing-masing aspek cukup besar.

2. Berdasarkan data hasil pengamatan diketahui bahwa siswa aktif selama proses belajar berlangsung.

3. Kekurangan pada siklus-siklus sebelumnya sudah mengalami perbaikan dan peningkatan sehingga menjadi lebih baik.

4. Hasil belajar siswsa pada siklus III mencapai ketuntasan.

Pada siklus III guru telah menerapkan model pembelajaran 
tuntas dengan baik dan dilihat dari aktivitas siswa serta hasil belajar siswa pelaksanaan proses belajar mengajar sudah berjalan dengan baik. Maka tidak diperlukan revisi terlalu banyak, tetapi yang perlu diperhatikan untuk tindakan selanjutnya adalah memaksimalkan dan mempertahankan apa yang telah ada dengan tujuan agar pada pelaksanaan proses belajar mengajar selanjutnya penerapan model pembelajaran tuntas dapat meningkatkan proses belajar mengajar sehingga tujuan pembelajaran dapat tercapai.

\section{Pembahasan}

\section{Ketuntasan Hasil belajar Siswa}

Melalui hasil penelitian ini menunjukkan bahwa model pembelajaran tuntas memiliki dampak positif dalam meningkatkan prestasi belajar siswa. Hal ini dapat dilihat dari semakin mantapnya pemahaman siswa terhadap materi yang disampaikan guru (ketuntasan belajar meningkat dari siklus I, II, dan III) yaitu masing-masing 66,67\%, $75,56 \%$, dan $86,67 \%$. Pada siklus III ketuntasan belajar siswa secara klasikal telah tercapai.

\section{Kemampuan Guru dalam Mengelola Pembelajaran}

Berdasarkan analisis data, diperoleh aktivitas siswa dalam proses belajar mengajar dengan menerapkan model pembelajaran tuntas dalam setiap siklus mengalami peningkatan. Hal ini berdampak positif terhadap prestasi belajar siswa yaitu dapat ditunjukkan dengan meningkatnya nilai rata-rata siswa pada setiap siklus yang terus mengalami peningkatan.

3. Aktivitas Guru dan Siswa Dalam Pembelajaran

Berdasarkan analisis data, diperoleh aktivitas siswa dalam proses pembelajaran Pendidikan Agama Islam pada pada pokok bahasan kisah-kisah Nabi dengan model pembelajaran tuntas yang paling dominan adalah bekerja dengan sesama siswa mendengarkan/ memperhatikan penjelasan guru, dan diskusi antar siswa/antara siswa dengan guru. Jadi dapat dikatakan bahwa aktivitas siswa dapat dikategorikan aktif. Sedangkan untuk aktivitas guru selama pembelajaran telah melaksanakan langkah-langkah kegiatan belajar mengajar dengan menerapkan model pembelajaran tuntas dengan baik. Hal ini terlihat dari aktivitas guru yang muncul di antaranya aktivitas membimbing dan mengamati siswa dalam menemukan konsep, menjelaskan materi yang sulit, memberi umpan balik/evaluasi/tanya jawab dimana persentase untuk aktivitas di atas cukup besar. 


\section{SIMPULAN}

Berdasarkan dari tujuan penelitian tindakan kelas (action research) untuk meningkatkan mutu pembelajaran yang terjadi di kelas, serta berdasarkan hasil penelitian yang telah dipaparkan selama tiga siklus, hasil seluruh pembahasan serta analisis yang telah dilakukan dapat disimpulkan sebagai berikut:

1. Model pembelajaran tuntas dapat meningkatkan kualitas pembelajaran Pendidikan Agama Islam, hal ini terlihat dengan ditandai dengan peningkatan ketuntasan belajar siswa dalam setiap siklus, yaitu siklus I $(66,67 \%)$, siklus II $(75,56 \%)$, siklus III $(86,67 \%)$.

2. Model pembelajaran tuntas dapat menjadikan siswa merasa dirinya mendapat perhatian dan kesempatan untuk menyampaikan pendapat, gagasan, ide dan pertanyaan, siswa dapat bekerja secara mandiri maupun kelompok dan mampu mempertangung jawabkan segala tugas individu maupun kelompok, serta penerapan model pembelajaran tuntas mempunyai pengaruh positif, yaitu dapat meningkatkan motivasi belajar siswa.

Dari hasil penelitian yang diperoleh dari uraian sebelumnya agar proses belajar mengajar Pendidikan Agama Islam lebih efektif dan lebih memberikan hasil yang optimal bagi siswa, maka disampaikan saran sebagai berikut:

1. Untuk melaksanakan model pembelajaran tuntas memerlukan persiapan yang cukup matang, sehingga guru harus mampu menentukan atau memilih topik yang benar-benar bisa diterapkan dengan model pembelajaran tuntas dalam proses belajar mengajar sehingga diperoleh hasil yang optimal.

2. Dalam rangka meningkatkan prestasi belajar siswa, guru hendaknya lebih sering melatih siswa dengan berbagai metode pengajaran, walau dalam taraf yang sederhana, dimana siswa nantinya dapat menemukan pengetahuan baru, memperoleh konsep dan keterampilan, sehingga siswa berhasil atau mampu memecahkan masalahmasalah yang dihadapinya.

3. Perlu adanya penelitian yang lebih lanjut, karena hasil penelitian ini hanya dilakukan di SD Negeri $060910 \quad$ Kec Medan Denai Pelajaran 2013/2014.

4. Untuk penelitian yang serupa hendaknya dilakukan perbaikanperbaikan agar diperoleh hasil yang lebih baik. 


\section{DAFTAR RUJUKAN}

Arikunto, Suharsimi. 2002. Dasar-

Dasar Evaluasi Pendidikan. Jakarta: Bumi Aksara.

Arikunto, Suharsimi. 2002. Prosedur Penelitian Suatu Pendekatan Prakte Jakarta: Rineksa Cipta.

Combs.

Arthur. W.

1984. The Profesional Education of Teachers.

Allin and Bacon, Inc. Boston.

Dahar, R.W. 1989. Teori-teori Belajar. Jakarta: Erlangga.

Departemen Pendidikan dan Kebudayaan, 1994. Petunjuk Pelaksanaan Proses Belajar Mengajar, Jakarta. Balai Pustaka.

Djamarah, Syaiful Bahri. 2002. Strategi Belajar Mengajar. Jakarta: Rineksa Cipta.

Djamarah. Syaiful Bahr 2000. Psikologi Belajar. Jakarta: Rineksa Cipta.

Hamalik, Oemar. 1994 Metode Pendidikan. Bandung: Citra Aditya Bakti.

Hamalik,Oemar. 2000. Psikologi Belajar dan Mengajar. Bandung: Sinar Baru Algesindo.

Kemmis, S. dan Mc. Taggart, R. 1988. The Action Research
Planner. Victori

Dearcin University Press.

Margono. 1997. Metodologi

Penelitian Pendidikan.

Jakarta: Rineksa Cipta.

Ngalim, Purwanto M. 1990. Psikologi Pendidikan. Bandung: Remaja Rosdakarya.

Nur, Moh. 2001. Pemotivasian Siswa untuk Belajar. Surabaya: University Press. Universitas Negeri Surabaya.

Poerwodarminto. 1991. Kamus Umum Bahasa Indonesia. Jakarta: Bina Ilmu.

Purwanto, N. 1988. Prinsip-prinsip dan Teknis Evaluasi Pengajaran. Bandung: Remaja Rosda Karya.

Rustiyah, N.K. 1991. Strategi Belajar Mengajar. Jakarta: Bina Aksara.

Sardiman, A.M. 1996. Interaksi dan Motivasi Belajar Mengajar. Jakarta: Bina Aksara.

Sukidin, dkk. 2002. Manajemen Penelitian Tindakan

Kelas. Surabaya: Insan Cendekia.

Suryosubroto, B. 1997. Proses Belajar Mengajar di Sekolah. Jakarta: Rineksa Cipta. 